\title{
PRODUCING CULTURAL SPACE IN THE CHINESE CITIES: A CASE STUDY OF GRAND THEATERS IN SHANGHAI
}

\author{
Charlie Qiuli XUE (D) ${ }^{*}$, Cong SUN (D), Lujia ZHANG (D) \\ City University of Hong Kong, Kowloon, Hong Kong
}

Received 12 July 2019; accepted 12 November 2019

\begin{abstract}
Following the rapid pace of urbanisation, Chinese cities have launched a new wave of large-scale infrastructure, including cultural building construction. From 1998 to 2015, more than 360 grand theaters were built together with libraries, museums and children's palaces. The number of newly built theaters may have been more than the total sum built in Europe over the past 70 years. Through case studies of theaters built in Shanghai, this paper penetrates the phenomenon of the "heat of cultural buildings" and discovers the history, intentions and effects of these theaters on Chinese cities. Following on-site investigation of the city and theaters, the materials of theater building in China are presented. Theaters of various types are discussed in the framework of urban space, design language and consumerist culture. The authors find that the rapid growth of cultural facilities epitomises the ambition and strong implementation of Chinese (and Asian) governments in the wave of urbanisation and globalization.
\end{abstract}

Keywords: cultural space, Chinese cities, grand theaters, Shanghai.

\section{Introduction}

With the opening ceremony held on August 27, 1998, Shanghai Grand Theater marked the beginning of a unique movement of theater construction in China. Until 2015 , the number of new theaters including new additions is 364 , in which 100 theaters are new constructions with an auditorium of 1.200 seats or more (Sun, 2019).

The name "grand theater" first appeared at a performing art center in 1989 in Shenzhen, a special economic zone bordering Hong Kong. In 1994, an international design competition of "grand theater" was held in Shanghai. Four years later a French designed theater clad with crystal clear glass and flying roof monumentally stood at the People's Square - the heart of Shanghai. The design of Shanghai "Grand Theater" was selected through international design competition - its quality and image were well worth and admired as "grand" by people of Shanghai and China. Since then, grand theaters were planned and built in various Chinese cities, from coastal metropolis to provincial city, from prefecture city to rural town center. "Grand theater" in this context is not only an auditorium. It usually contains an opera house, a concert hall and a multi-functional theater. Most of these grand theaters have a gross floor area between 10.000 to 50.000 sq. m., and the total construction cost is about RMB 100 billion yuan (around USD 16 billion). ${ }^{1}$

Why and how have so many grand theaters been built so quickly? How were those designs selected in the process of decision making? What is the design language of the grand theaters? How do these theaters influence the ambience of a city, and how do they provide public space and amenities for a vibrant civic life? Cultural buildings are being busily constructed, cement, steel and materials are quickly consumed, but few serious studies have been carried on the heat of grand theater construction in China.

This article attempts to answer these questions using Shanghai as an example. After 20 years' observation (since their inception) and investigating on-site the newly built and old cases, the authors hope to examine how a grand theater is built with a particular mission in urban renewal and new town construction and how they interact with Chinese urbanization in the tide of globalization. Shanghai has long been recognized as the most advanced city and role model in China in terms of economy and life style. The situation in Shanghai can epitomize the direction of Chinese cities in general.

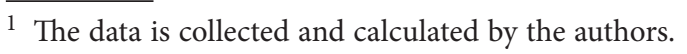

*Corresponding author. E-mail: bscqx@cityu.edu.hk 


\section{Literature review on cultural buildings}

Performing art is part of entertainment activities of the human being. Conventional study of theater concentrates on theatrical technology, sightline and acoustics (Izenour, 1996; Cheng, 2015). After the $19^{\text {th }}$ century, theaters have been built more for city's pride, symbol and confidence. When Garnier's opera house was built in Paris in 1861, it was a high-class venue of performance and social life. Its Baroque image was part of the Parisians' pride (Cheng, 2015).

In the 1950s, the city of New York cleared slum area in Manhattan and built Lincoln Center, with three highend theaters, several concert halls and more than $70 \mathrm{mu}-$ seums and libraries nearby. This lifted New York from a financial center to a cultural metropolis. Sydney Opera House stood on Bennelong Point of Sydney Harbor in 1973, Utzon's shell-shape design made it far more than a theater for the city (Murray, 2004). After that, municipal leaders and people began to learn how a cultural landmark had helped promoting the image of a city significantly. In France, President de Gaulle believed that bringing high culture to the masses would contribute to creating a more educated and productive society (Grenfell, 2004). In the 1980s, Mitterrand's state projects in Paris revitalized this economic and cultural capital of Europe. The old facilities were rebuilt, like the Louvre; and new facilities were constructed, like opera house in Bastille and the national library (Enright, 2016). In 1997, the Guggenheim Museum in Bilbao, Spain greatly revitalized the originally derelict industrial town, population around 250.000, and attracted more than one million tourists annually, creating the so-called "Guggenheim effect" (Jencks, 2004). Cultural buildings and theaters have always been strongly tied with progression of urbanism and city status. Such cultural flagship projects and icons helped cities to create positive urban images as a great place to live and work, attract economic investment and talents, develop their tourism sector and enhance their competitiveness among the rival cities (Kong et al., 2015; Chang, 2000). Mr. Peter Karl, the founder and chairman of Global Competition Union said in the 2014 United Nations "World Cities Day" Forums that another competitive element in a successful city is architecture (Xiao, 2015).

All those foreign landmarks, events and city spectacles have been inspiring China when the country got away from political turmoil and returned to normal life in the 1980s. Before 1980, the occasional performing art buildings were linked with power and Unitarian rules, for example, Great Hall of People in Beijing and some provincial cities (Xue, 2006; Xue \& Ding, 2018). The movement of constructing grand theater in China is accompanied and fueled by constant economic growth, rapid urbanization, new town construction and old town renewal. The newly built grand theaters in China may outnumber the sum of similar buildings constructed in Western hemisphere since World War II. No other country has constructed so many grand theaters and cultural buildings in such a short period, which raises a number of issues of general concern.
To answer the questions raised in the beginning of this paper, we plan to discuss several aspects of the theater phenomenon, just using historic narrative method with the background of China's social change. The authors have compiled database of Chinese newly built theaters and investigated targeted buildings. The following sections are organized under such subtitles as (1) initiation of performing art buildings; (2) design, selection and decision making; and (3) role of grand theaters in city. This study aims to shed light on the rapid development of Asian cities, reveal the problems attached to these prominent landmark buildings and fill the academic gap in cultural building study and Chinese architecture.

\section{Initiation of Grand Theater}

As theater's huge investment and the government control of money, planning and land-use, most theater planning and construction are in the public sector with top-down procedure and implemented as political tasks. There are a few theaters and museums run by the private corporations, however, these corporations usually have governmental and military background in China. The initiation of cultural mega-structure is mingled with governmental imperatives in different historical periods. In Shanghai, it can further be categorized to (1) restoring historic glory; (2) vitalizing (remote) areas and (3) fulfilling actual needs of cultural production and consumption.

\section{Restoring historic glory}

As an early "global" city in the eastern China, Shanghai was exposed to Western civilization in the late $19^{\text {th }}$ and early $20^{\text {th }}$ centuries. Western management and materialistic advancement transformed the city into a modern society, which attracted millions of people from nearby provinces and foreign countries. Between the two World Wars, Shanghai was under the spotlight in the Far East and was nicknamed the "Oriental Paris": its ports, factories, garden houses, department stores, hotels and apartment buildings were a physical manifesto.

In its heyday, performance halls and cinemas were constructed in the concession areas. These cultural facilities, together with dancing halls, luxurious hotels and apartment stores, splendidly gilded the city center (Figure 1). In 1908, Hongkou Theater (designed by L. E. Hudec), the first cinema in Shanghai was built. From 1930 to 1935, the famous Nanking Theater (later renamed Shanghai concert hall, designed by Fan Wenzhao, 1930), Strand Theater (designed by Elliott Hazzard, 1930), Lyceum Theater (designed by Davies \& Brooke, 1930), Cathay Theater (designed by C. H. Gonda, 1930), Metropol Theater (designed by Allied Architects, 1933) and The Grand Theater (designed by L. E. Hudec, 1933), etc. were built, which has led to the development of public culture in China. At that time, most of the theaters were designed by foreigners and can be compared with those in New York. Going to the theater to watch a movie became a symbol of identity 


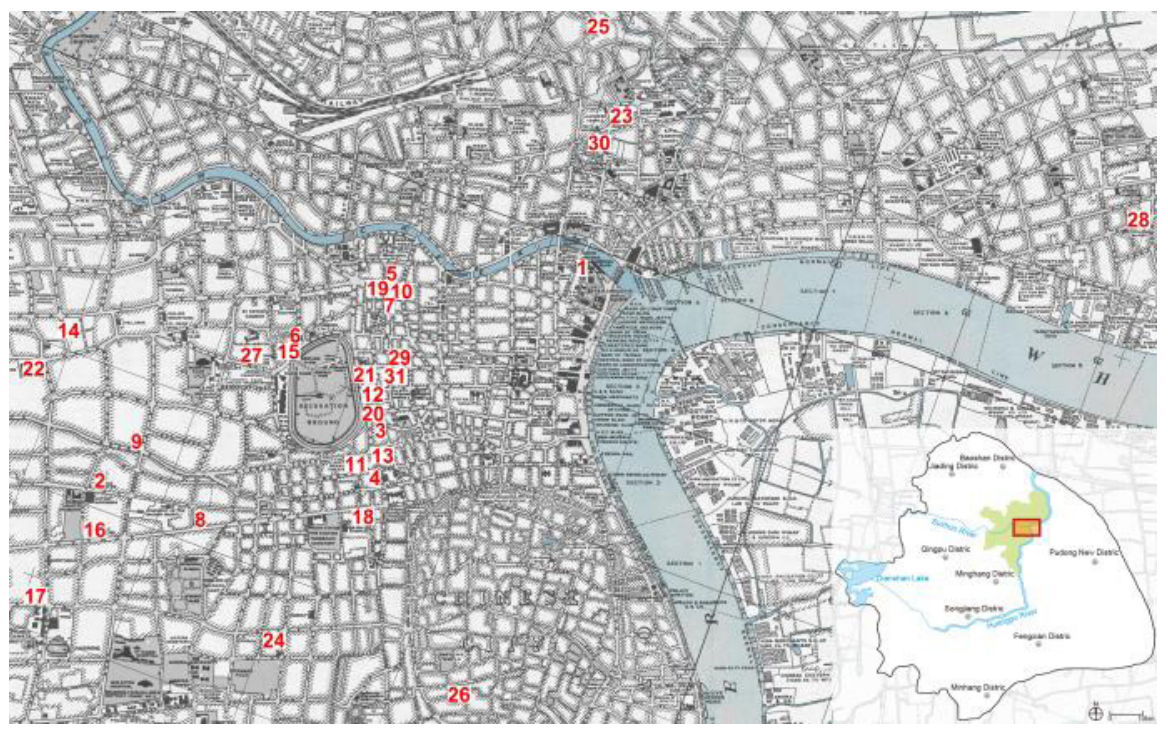

Figure 1. Distribution of main theaters and cinemas in Shanghai in the 1930s (numbers represent the spots, names are deleted for the sake of page limitation)

and wealth. In 1949, the number of theaters in Shanghai reached 43 and 21 of them had more than 1.000 seats. This number dwarfed the other Asian cities at the time (Zhang, 2005). A lot of famous writers and artists emerged in this environment. After the Communist Party took power in 1949, Shanghai was planned as an industrial base. Sporadic cultural pavilions and cinemas were built together with workers' residential areas at the city's periphery. In the wave of building grand projects to symbolise the strong socialist dictatorship, Shanghai once prepared blueprints for an opera house that could seat an audience of 3.000, but the project had to be shelved because of economic difficulties in the early 1960s.

In 1978, China embarked on its open-door policy and began to eagerly learn Western technology and management. At the time, Shanghai was embarrassingly dilapidated, and its only remaining grace came from its old 1930s foreign concession legacies, a source of pride for Shanghainese. However, in the early years of the open-door policy, Shanghai was busy housing its residents and building hotels and offices for the burgeoning market business after decades of delay. The city took off again when Pudong, the east bank of the Huangpu River, was developed in 1990. In 1993, the GDP of Shanghai was US $\$ 1.500$ per capita (Shanghai Statistic Bureau, 2018).

Although the city was still in the lower-middle income stage, the construction of cultural buildings was tabled in the government's agenda because "Shanghai was seeking to reclaim its pre-communist role as China's world city" (Short, 2004, p. 21).

In early 1994, violinist Itzhak Perlman and the Israel Philharmonic Orchestra toured Shanghai, but the city lacked a qualified professional concert hall, which left Perlman disappointed. The highest-class performing facility was the conference hall of the municipal government, a temporary pavilion remodelled from an old building in the 1950s. The event shocked the government. Huang Ju, the mayor, pointed out that cultural construction must be achieved in tandem with economic construction. The government planned to build a grand theater, "lifting the face for Shanghai people, and being responsible for the future generations" (Yu, 2014). The grand theater transcended a cultural performance building to become a symbol of political statement and a powerful gesture of the "open door".

Vice-mayors Gong Xueping and Chen Zhili selected a site next to the municipal government, facing the People's Square. In the socialist period, the capital city, Beijing, built Tiananmen Square, which could accommodate a million people for political gatherings, demonstrations, and festival parades. The other cities followed this model and built their own political centers. People's Square in Shanghai exactly parallels the function of Tiananmen Square in Beijing. The municipal government occupied the old Hong Kong and Shanghai Bank building in the Bund in the 1950s to 1980s. In the years of the open-door policy, the municipal government returned the building to the banking industry, and the new building was set at the central axis, north of the People's Square. On the opposite side is Shanghai Museum. The grand theater stands to the west of the government building, and the Shanghai Planning Exhibition Pavilion is on the east. The siting strategies of the grand theater and museum show the government's determination to govern the city with soft and cultural power. Grand theaters and museums are given sacred status by placing them in the city's heart (Yang, 2016) (Figure 2).

After almost 20 years, Shanghai already possesses 7-8 mega-structures of performing art space. The government still planned to build Shanghai Opera House, to chase back its dream of 1960, when Shanghai raised its proposal as the first city in China to have grand opera house (Figure 3). After World Expo in 2010, the site of $5 \mathrm{sq}$. km. left 

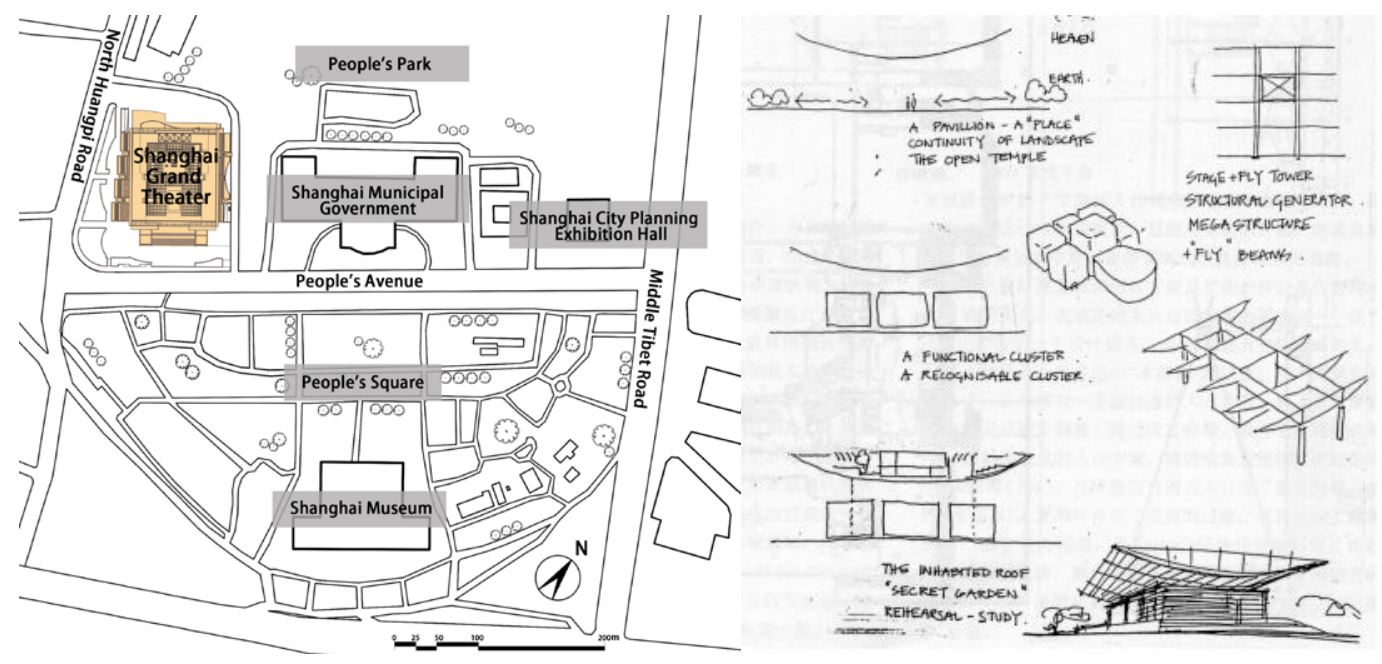

Figure 2. Master plan and sketch of Shanghai Grand Theater

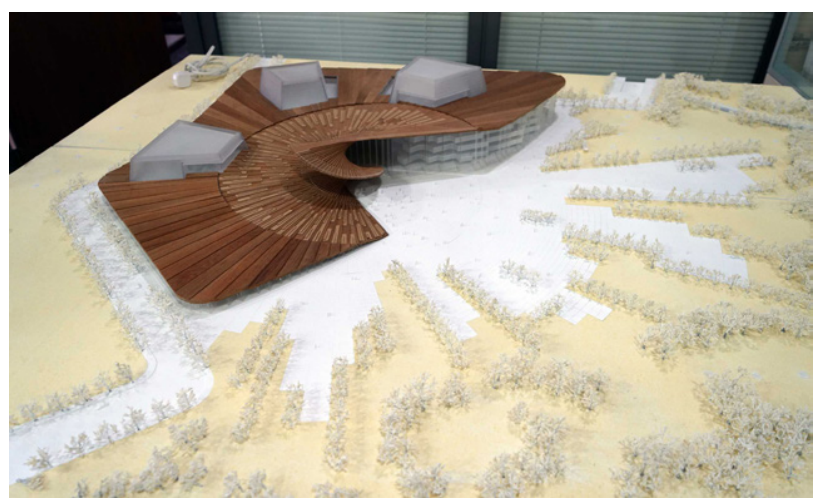

Figure 3. Shanghai Opera House, designed by Snøhetta of Oslo and East China Architectural Design Institute of Shanghai, under construction in 2019

many buildable land parcels for cultural building. The new Shanghai Grand Opera House naturally sits in the riverside. As the planning authority firmly implemented the government's mission and vision, the land plots in prominent locations are first considered for cultural landmarks.

From the above narration, one can see that the ambition of "restoring" and climbing to the higher city status always fuels the construction, similar as the determination of Paris in the 1980s. Different cities have different source of historic proud. Comparing to those hinterland towns with thousand years' splendid history, Shanghai was only a small county in the mid- $19^{\text {th }}$ century when British merchants leased a parcel of land for trading. The influx of western civilization quickly elevated Shanghai to an oriental metropolis and role model of Asia in the 1930s. The "glory" originated from this unforgettable period (Lee, 1999). This leading position was bestowed from being "westernized" and consensus of municipal leaders and general public, evidenced by numerous publications after 1978 (Shen et al., 2016; Zhang, 2005). To restore its glory, Shanghai must be leading in every trade, especially in producing grand and fabulous cultural space.

\section{Stimulating remote area}

In the mid- $20^{\text {th }}$ century, China was still an agricultural society. Chairman Mao Zedong (1893-1976) and the communist government had attempted to realize a strong industrial economy, but new factories mostly were located in remote mountain areas for the purpose of national defense, so this early industrialization program had little impact on cities. When China launched the "reform and open-door" policy in 1978, the urbanisation ratio was only $18 \%$, but later it jumped to $47 \%$ in 2009 and reached 57\% in 2016. Almost one billion Chinese people will live in urban area in the near future. One of the most stunning statistics able to illustrate this singular urbanization is the consumption of cement. According to statistics from the United States Geological Survey (USGS), from 2011 to 2013, the three-year usage of concrete (6.6 gigatons) in China was more than the total usage of concrete ( 4.5 gigatons) in the United States during the entire $20^{\text {th }}$ century (Gates, 2014; Smil, 2014).

Building the city for integrating global economy is the ultimate goal of Chinese urbanisation, so new urban designs should not only accommodate the population explosion (immigrants from rural area) in the city, but also improve the living and working environment. Many old towns with mono multi-story residential buildings are incapable of providing sufficient spaces and compatible facilities for modern lifestyle and business. When urban renewal in old districts faces bottlenecks, new town development becomes an effective option widely adopted by many cities. New towns or new zones are planned in almost every provincial capital city, with provisions of a new administrative center and a grand cultural center as the trend of urban design. The size of those new towns is ranged from 10 to $150 \mathrm{sq}$. km., eroding huge amount of arable lands at the once suburban area.

When Pudong, east bank of Huangpu River was planned in 1990, it was regarded as a new office area to 


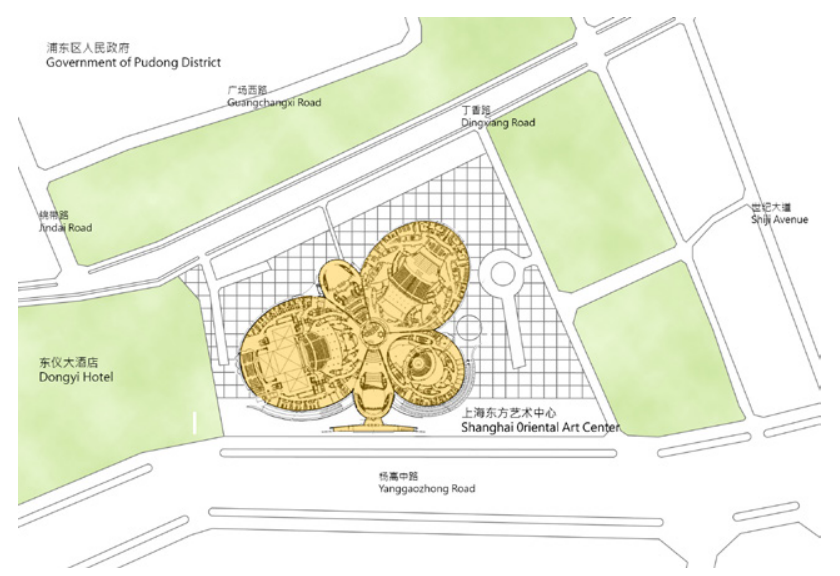

Figure 4. Master plan of Oriental Art Center

solve the insufficient land supply in the old city area, west river bank. Shanghai people would rather "keep a bed in the west bank, instead of having a flat in Pudong" (a popular saying). To make Pudong livable, the local government thought of adding facilities including libraries and performing buildings. An Oriental Concert Hall designed by Japanese architects was planned in Lujiazui of Pudong (Wu, 2012; Nippon Shekki, 1995). The site was found to be too small, and the oriental concert hall was moved to the administrative district of Pudong. By taking this opportunity, the Pudong government hoped to make it more than merely a concert hall (Figure 4).

The original concert hall was expanded to three performing spaces under one roof and named the Oriental Art Center. It was designed by French architect Paul Andreu (1938-2018), who had already designed the Shanghai Pudong Airport terminal in 1997 and the National Grand Theater in Beijing in 1999. Andreu is fond of symbolic shapes, which the decision makers in China also enjoy. In the Oriental Art Center, Andreu designed a five-petal magnolia, the city flower of Shanghai. The three large hemispheric petals are the concert hall (2.000 seats), opera house (1.100 seats) and recital hall (300 seats), and the two small ones are the entrance and exhibition hall.

Pudong was vitalized by fast-growing number of new cultural buildings, like Oriental Art Center, libraries, museums, parks and new types of residential estates. It is soon integrated with the west side of Huangpu River, and regarded as a high quality location for living and working in the $21^{\text {st }}$ century.

Similar role of cultural building as magnet took place in the remote Jiading District. Dr. Sun Jiwei, graduated from Tongji University, was responsible for the town planning and construction in Qingpu and Jiading, both old rural towns in Shanghai, in the $21^{\text {st }}$ century. He believes that excellent architecture can light up the old towns. This has been proven successful by practice like starchitects Frank Gehry in Bilbao, Prague or Zaha Hadid in many European and Asian cities. During Sun's time in Qingpu, he created many opportunities for elite architects to build experimental architecture in his district. The rural towns have more land than the crowded city and thus more freedom for designers' creativity. When he moved to Jiading, he planned a new $\mathrm{CBD}$, parks and landscapes for the district and invited famous architects from home and abroad to design public buildings. When the land for a theater was leased to the Poly Group, the Group committed a design. However, as a district planner, Sun hoped to have a world class architect who could "light up the area". With this thinking, he and the client invited Japanese architect Tadao Ando, who was said "to understand China's construction conditions and be flexible enough" (Ma, 2015).

Many world cities will welcome designs from such a Pritzker Architectural Prize laureate. An old rural town between Shanghai and Jiangsu Province, Jiading has hosted a Volkswagen production line, "German Town", a Formula One racecourse and some ancient heritage. The Jiading New Town is one of the three new towns planned to upgrade suburban Shanghai, and it will house up to one million residents. From one of the "One City Nine Towns" strategy to one of the "Three New Towns" and then to the "City Sub Center", Jiading's position has been considerably enhanced and it only took less than 15 years (Xue \& Zhou, 2007). During its rapid development, it has had Tadao Ando's name and skilful design to lift its face. Tadao Ando had not previously designed a grand theater and grasped the opportunity to make this statement and add to his already brilliant portfolio. Although far $(28 \mathrm{~km})$ from the city center, Poly Theater has served residents of Jiading with its own performing niche in the nearby areas since its opening in 2014 (Figure 5).

Next to the theater, is Jiading Library designed by a Chinese star firm MADA s.p.a.m. The library was unknown till American magazine Interiordesign reported it as the "best public library in the world" in 2015. The number of readers and visitors soar up afterwards.

Without these starchitects' buildings, those remote areas might still sleep in an unknown world (Xue, 2010). After these landmark buildings, developers are attracted, large-scale real estates and shopping malls were developed in nearby. Young middle class people are willing to work in Jiading's factories and research institutes, and enjoy better environment than the old city area. They can read books in comfortable library and bring kids to theater at weekend. The grand theaters, library and cultural buildings add surplus value to the area.

\section{Fulfilling actual needs of cultural production and consumption}

Art was part of the civic life when Chinese cities like Shanghai entered modern time, as mentioned in the previous session. In the eyes of the Communist Party, "art is a powerful weapon of uniting people, educating people and beating the enemy" (Mao, 1991). In the Communist fortress of Yan'an during 1938-1946, auditorium of wood structure was built and revolutionary plays were staged to motivate morale of cadres and masses. The multifunctional auditoriums were sporadically erected in Mao 


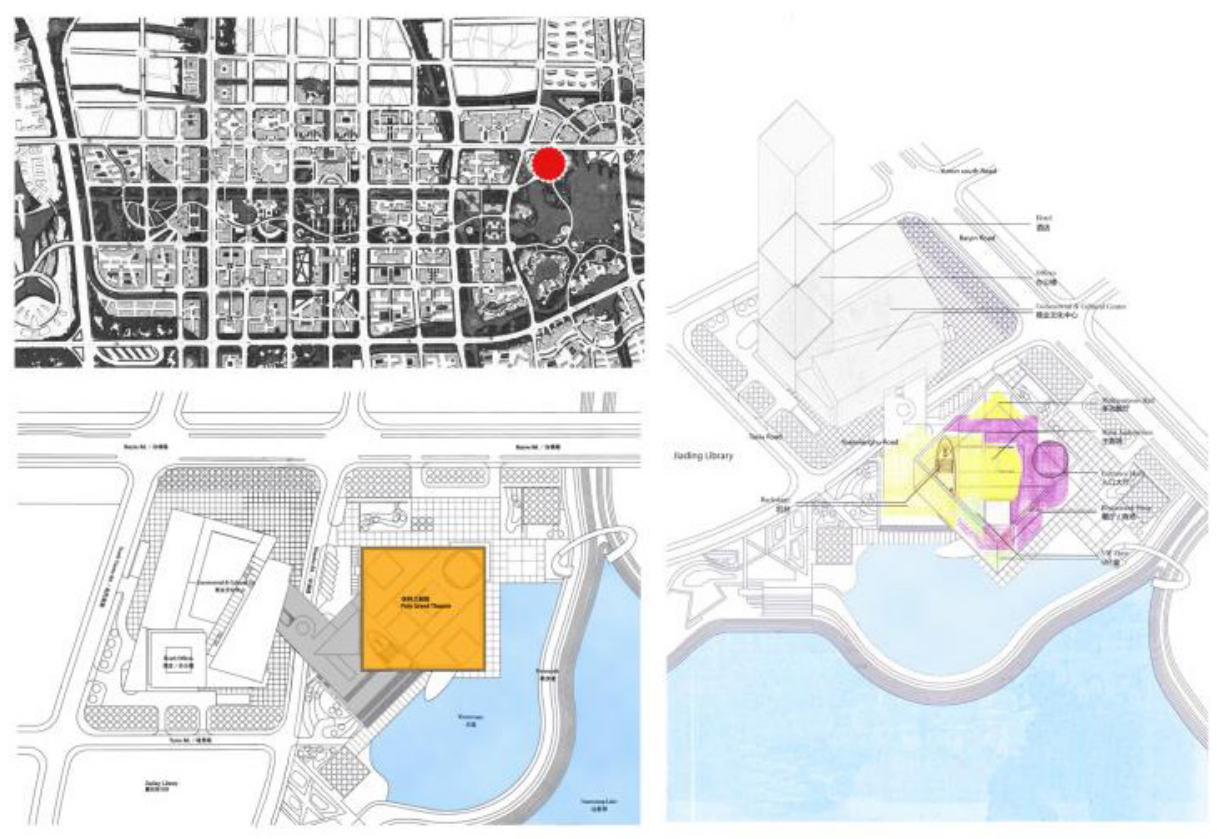

Figure 5. Master plan of Poly Theater

Zedong's era in the 1950s. When economy allowed, the auditorium would be built in larger scale; or in stringent time, smaller scale by simple technology. These auditoriums were mainly used for political assemblage, a typical one in Shanghai was Cultural Square, built in 1956. The structure was renovated from a 1920s-greyhound racing course as a semi-open structure to accommodate 15.000 people. Gambling was not allowed by the Communist government, but the large space could be reused.

When the open-door policy was adopted and market economy replacing the planned one, political gathering gives way to cultural consumption. The focus of government administration was shifted and translated to modernize China and to improve people's living standards in the 1990s. At the same time, civil servants, institutions and big companies changed from six working days to five working days a week. Since then, the number of highincome urban elites has gradually increased and the middle class has emerged. They have a strong purchase power of high-end cultural activities and boosting the show and performance business. Through viewing some kinds of performances, the middle class marked its special taste, and their distinction and distance to other people in society (Bourdieu, 1984). In 1996, the central government issued an instruction to build 50 or more cultural facilities nationwide, such as libraries, museums and theaters "which are compatible to economic level and represent the image of the state and relevant cities" (Ministry of Culture, 2007). The spectacle and consumption-based economies work through the generation of new needs for increasing people's expenditures. Through going to concert, opera, Xiqu (folk opera) and other kinds of entertainment, audiences have shown their preference, choice and taste in cultural and leisure activities. "When cities are dominated by the service economy, aesthetics plays an important role in the use of space and lifestyles" (Zukin, 1993).

The massive cultural consumption stimulated cultural production and its facilities. Some theaters were born in this tide. For example, the Shanghai International Dancing Center consolidated several dancing troupes and planned a base of rehearsal, performance and school in the west part of Shanghai. Based on this center, the city organized a series of international dancing competitions.

Shanghai established the earliest philharmonic orchestra in China, by the International Settlement in 1922. Before the orchestra had its own concert hall, the musicians packed into a small house to practice, where noise from street and next door was inevitable. When music was recorded, even in the summer, the air-conditioning had to be shut down. In 2009, Shanghai government gave the old Shanghai diving pool to the orchestra to build its concert hall. The site is in the city center, where Metro Line 10 passes underground. The client first found the acoustic consultant Yasuhisa Toyota from Japan, who had designed concert halls for Suntory in Tokyo and Disney in Los Angeles. An architectural design by Japanese architect Isozaki Arata was selected from four competitors, and Tongji University design institute assisted as the local architect (Figure 6).

The Shanghai Symphony Orchestra moved into its new home in 2013. The venue is near the Conservatory of Music, so the art teaching/learning and performing can include more interactive communication in a walking distance. Not only does the orchestra rehearse and perform in the concert hall, but it also hosts touring international music troupes. The building enhances the status of Shanghai's symphony orchestra, which is able to attract better musicians and more sponsorships. 

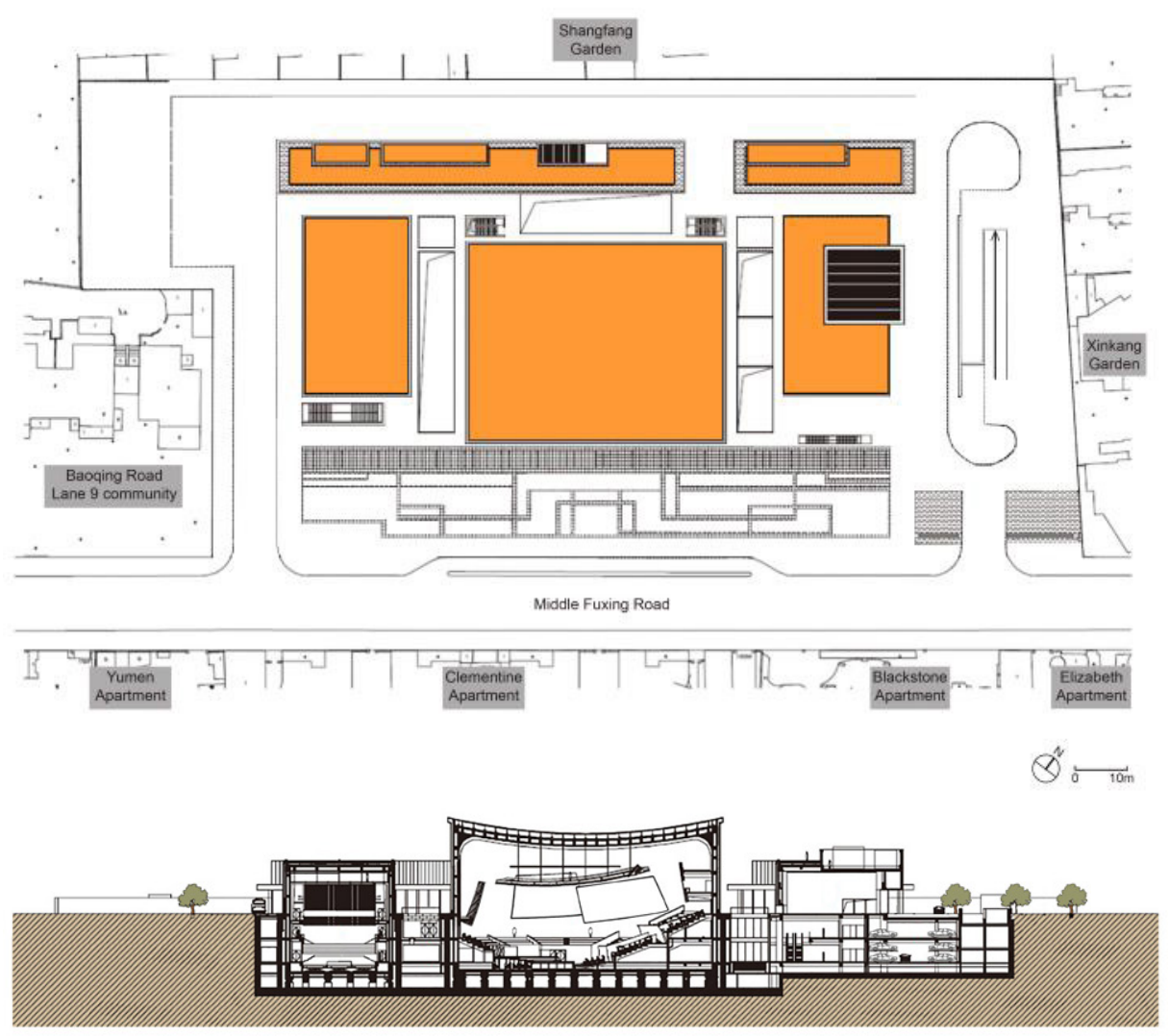

Figure 6. Master plan and section of Symphony Orchestra Concert Hall

For a city of 24 million population and the richest one in China, the GDP per capita is around US\$ 20.000 in 2017 (Shanghai Statistic Bureau, 2018). This attains to a middle-high income rank. People have extra money after food and clothing. Compared to the data of London, the number of theaters and seats in Shanghai is not sufficient. ${ }^{2}$ Building grand theaters helps the city in restoring its historic glory, revitalizing the new district, and at the same time, satisfying the increasing societal demands.

\section{Design and decision making}

Theater design in China typically reflects the trend of Chinese architecture in the past 40 years. In the industrialization period, Chinese architecture was designed under the governmental principles of "pragmatic, economical and delightful if possible". However, after 1990, Chinese cities determined to catch up with the global cities, and landmark public buildings were laden the expectations of "lighting" the district and city. Local Chinese architects were long trained in the pragmatic, economical way and simple technology, and the task of projecting international image had to leave to the international bidding and "grand design" (Xue, 2010).

\footnotetext{
2 About the theater and performances in London, see BBC's report. http://www.bbc.co.uk/programmes/b08yqb9r, July 29, 2017.
}

Shanghai Grand Theater is among the first group of public buildings for international competition. Through the invited consultation for Lujiazui CBD planning in 1992, Shanghai municipal government enjoyed fruitful new ideas of international consultants. An international design competition was held in early 1994, and the French firm Arte Charpentier Architectes stood out from 18 architectural firms around the world. Charpentier's design featured a reverse flying roof supported by a truss, with a crystalized white glass box inserted under the roof. The rear of the site is against the old Jockey Club (which was the city library at the time), so the length is limited. The grand theater consists of a lyric theater of 1.631 seats, a drama theater of 575 seats, and a studio theater of 220 seats. The front lobby links only to the lyric theater. The other two small theaters take the back and leftover space. Their entrances are on the side, without a spacious lobby. Therefore, only the lyric theater can cater to all major performances. Under its thick roof are restaurants and cafés. The reverse flying roof resembles a sacred palm gesture toward the sky.

The Shanghai Grand Theater stood out from the Chinese architecture at the time. This was the first international design competition of cultural building in China and set an example for other cities. Arte Charpentier Architectes is not an avant-garde firm in France, but good at understanding the needs of clients. The designer Andrew Hobson's concept of "sky" and "earth" soon captured 
the heart of Shanghai's decision makers. These municipal leaders in the 1990s respected French as "high art creator", and they also liked gesture of "symbolizing" the Chinese culture (Figure 7).

Shanghai Grand Theater and several landmark buildings designed by foreign architects at the turn of the century sent a clear signal that building image (icon) is more important in a consumerist and information society. Oriental Art Center proved this trend again. As mentioned in previous session, Paul Andreu's design of five-petal glass "flower" is consistent with his design language in China, and well recognized in the district and city. Drawing experiences from Sydney Opera House, Andreu understood the importance that "elevations must be decent in all directions". The three performance halls are relatively enclosed, and the leftover space is for public use. In other words, the indoor public space serves three performing spaces. The performance space is enclosed by a thick concrete wall, from which steel rods support the external curvilinear curtain wall. The external wall is made of bulging glass curtain, and all internal walls are decorated with warm-coloured porcelain panels.

Compared to Shanghai Grand Theater, Oriental Art Center has stronger iconic effect, which helps to highlight the new Pudong district (Figure 8). This symbolic and slightly radical design displayed effective impact in

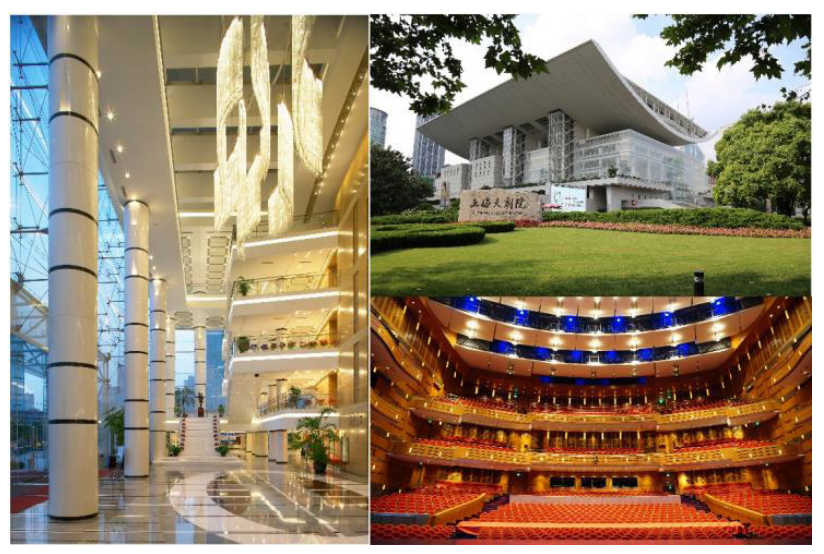

Figure 7. Shanghai Grand Theater: elevation, lobby and auditorium suburb, where rare public buildings on flat land easily become abstract sculptures. 10 years later, when Tadao Ando designed Poly Theater for Jiading, he pushed this direction to the utmost.

Tadao Ando began his China venture in 2004 and has designed nearly 20 projects in various cities. He is highly esteemed and eagerly sought after, and his designs have won enthusiastic applause from municipal leaders and clients. The Poly Theater is located at the end of a road axis facing a large park and man-made lake. The basic building form is a square $100 \mathrm{~m}$ on each side. A 1,575-seat theater lies diagonally in a 34-m-high square box. The central axis of the auditorium extends to the main entrance in the corner. Four groups of cylinders, $18 \mathrm{~m}$ in diameter, are inserted into the box. They interconnect and form a complicated interior space and are reflected on the external wall. Through the dramatic holes on the external wall, people from the park can peep into the internal space, like a "cultural kaleidoscope". The lake is extended to the theater, and an open stage projects into the water. The huge double-curved surface is cladded with aluminium strips, which have a timber-like texture after heat treatment. According to Ando, wind and light in these complicated spaces are making another play (Ando, 2015; Chen et al., 2015). The fare-faced concrete wall is veneered by a second skin curtain wall, which soften the external wall in daytime and lighten up by flooding light in the evening. $\mathrm{He}$ continues his design language of fair-faced concrete and curtain wall. Ando's design may look too strong in a city environment, but displays a sculptural effect in a big park of suburban town (Figure 9).

In a consumerist and digital society, cultural buildings' first function is to provide a space for leisure, therefore, aesthetics is prioritized. In numerous media and selfmedia, building images spread fast and reach people's eyes, before most people have opportunity to go there by themselves. Buildings with strong design and breaking image are easy to be supported by the decision makers, who wish their buildings "not backward for 50 years". The winning theater designs in Shanghai and China satisfy the eyes of political leaders and jury committee members, and get constructed in this social atmosphere. Domestic and foreign architects who want to bid jobs in China gradually
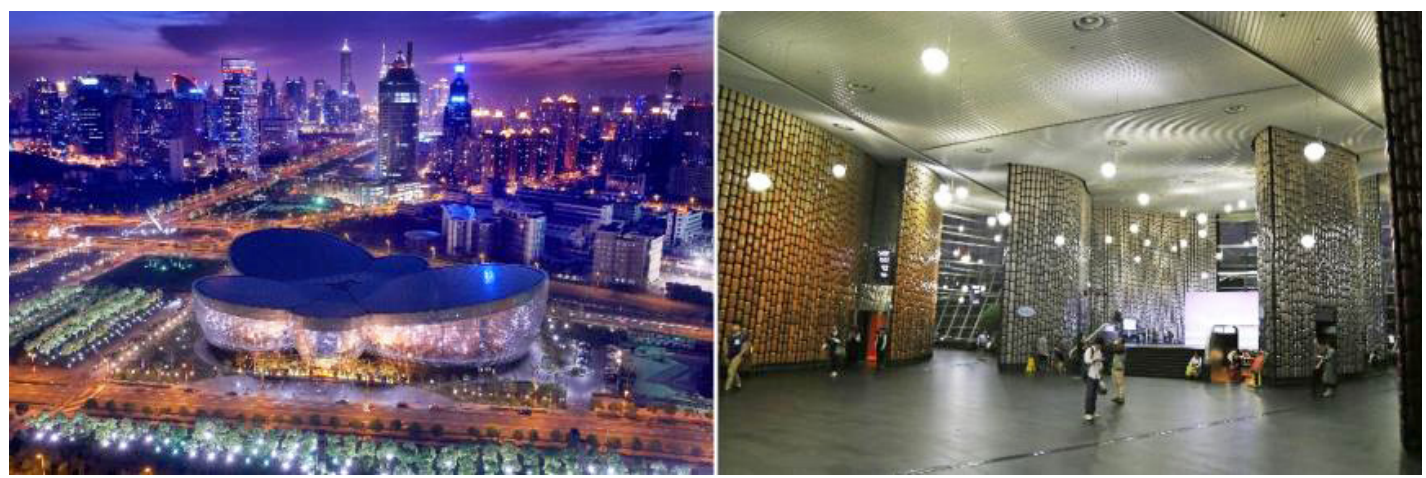

Figure 8. Oriental Art Center, building and lobby 


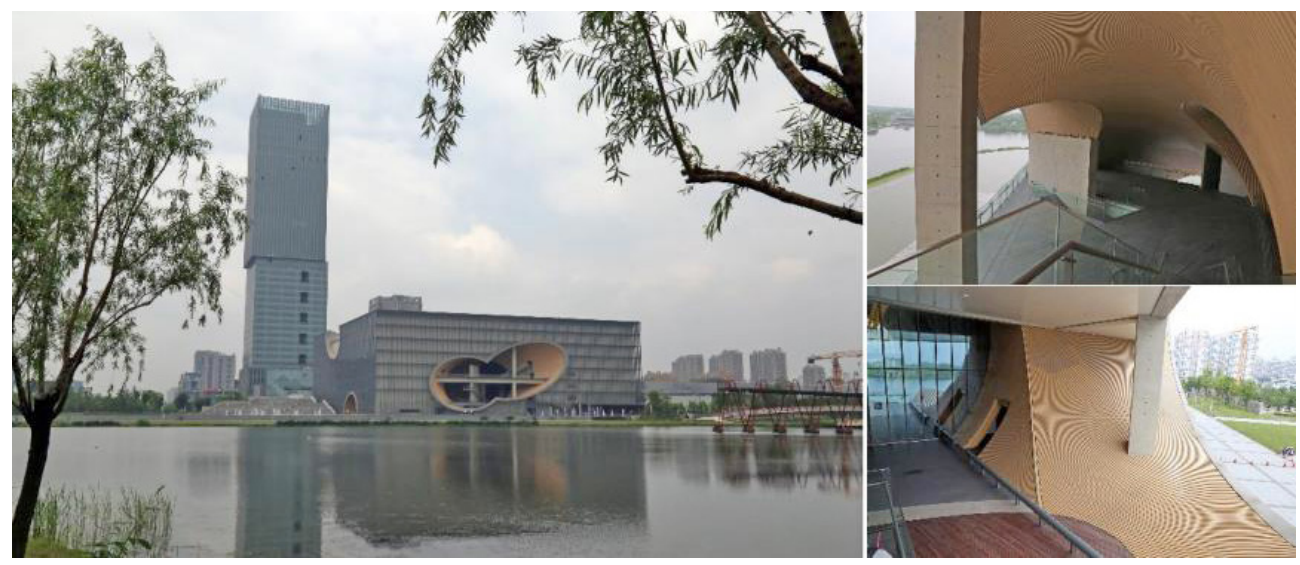

Figure 9. Poly Theater, building and lobby

understand this principle, and they try every method to please the client. Looking at the world architecture in the past 30 years, similar method of design won most of the important cultural projects.

\section{Grand Theaters in the urban environment}

For a grand theater building, government usually invested around a billion yuan RMB (around US\$ 160 million) for construction in the $21^{\text {st }}$ century. Even in the Western countries' term, this is not a small sum. As the decision and investment are in a top-down manner, decision makers mainly consider how the grand project can enhance the soft-power of the city. The end-users' opinions are bypassed. In their operation, most theaters assume a selfreliant mode and run on incomes from box office and sponsorship, without government's further subsidy. Those cultural buildings consolidated Shanghai as a cultural capital and its status as international city. Can these buildings contribute to an active civic life of people?

The theaters mentioned in this paper, Grand Theater, Oriental Art Center, Poly Theater, and Symphony Orchestra Hall, each usually hosts more than 300 performances a year. Every day, they are either in performance or in installing the stage setting. This number of shows closes to those in Hong Kong, London and New York's main theaters. ${ }^{3}$ The performances are from the local troupes, international itinerating artists, and small portion of program is made by theaters themselves. The frequency of performance in China correlates with city's civilization and gross domestic product (GDP) level. In some hinterland cities, a fabulous theater can hardly run two shows a month, or be filled only with children's program.

Because of its important location and unique image, Shanghai Grand Theater often appears in postcard and

\footnotetext{
3 The authors investigated the performance situations of Festival Hall, Royal Opera in London in November 2018, Lincoln Center, Carnegie Hall and Radio City Music Hall in New York city in October 2019. The shows staged on these theaters average around 250-300 a year. Hong Kong's number is from Yearbook of Cultural Center, 2014-2017.
}

leaflets of tourist information. However, an iron fence surrounds the outdoor grassland. Passers-by can only appreciate the crystalline sculpture-like theater at a distance. Many residents in the surrounding areas never have a chance to enter the theater. The management has explained that there are too many people in the square. If the theater removes the fence, tourist buses will park in front and damage the pavement. Opening the lobby to the public is unthinkable. ${ }^{4}$

In the Oriental Art Center, people can enter the box office only after passing through security guards and an $\mathrm{X}$-ray bag check. After buying tickets, people are allowed to enter the lobby, which connects to the three performing spaces. As it is far from the city and the Metro line, and because of the strict entrance security check, very few people will be in the mood to stroll through the lobby during the day.

Although it is located in remote suburb, Poly Theater treasures its state and image same cautiously. The lobby opens to the public on the second Sunday every month, but only for four hours. Most people can only enjoy its heroic profile from the park. Just because of Tadao Ando's semi-open design, the theater management is unable to completely bar people from entering the big holes. Many nearby residents can walk to the podium through waterfront amphitheater and peer the inside "kaleidoscope" space.

The concert hall of the symphony orchestra is among the very few theaters that open to the public their lobby and exhibition gallery, where musical instruments and interactive sound devices are displayed. It is aligned with other buildings in the street of the old French concession area. Because it partly sinks into the underground, pedestrians could hardly find its full face on the tree-lined road. It is modest and intimate and not as glamorous as the other grand theaters (Figure 10). Among more than 20 major theaters we investigated in the Chinese cities,

\footnotetext{
4 The management situation is taken from the interview of general manager Ms Zhang Xiaoding, engineer Wu Zhihua and executive officer Pan Lan on July 3, 2017.
} 


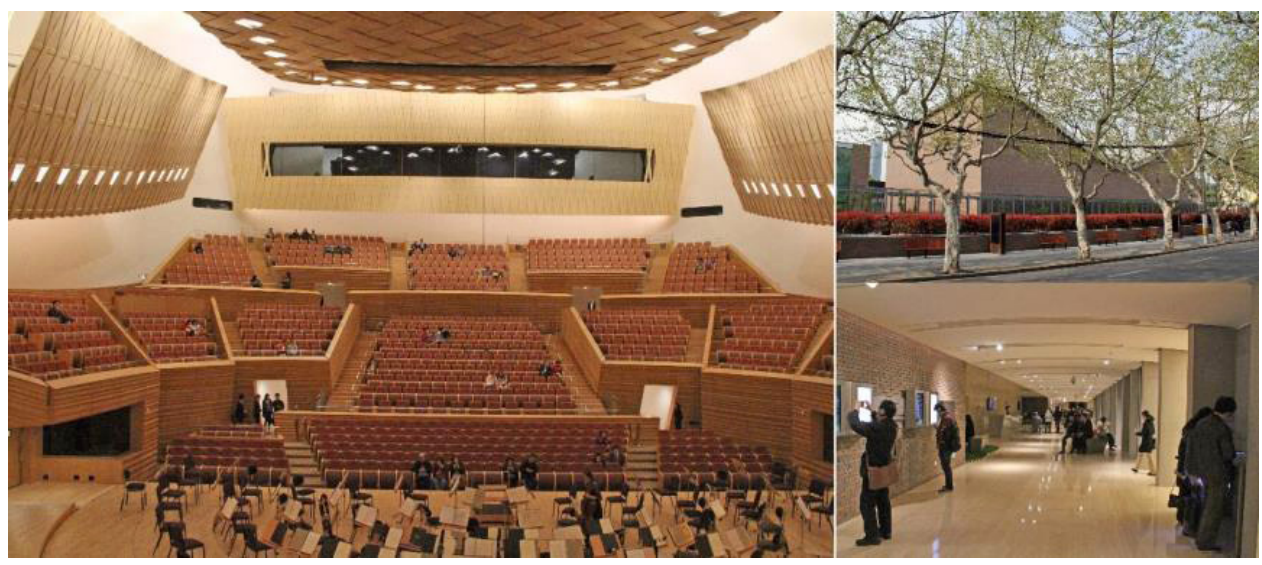

Figure 10. Symphony Orchestra Concert Hall, building and lobby

$80 \%$ shut people outside in day time. Even in the evening before the show, some theaters only allow audience members to enter the lobby from side gate. The grand front entrance is always fenced.

Although designers have good intentions of providing public space and promoting civic activity through buildings, theater management in China tend to maintain their buildings in a "clear" way with less wear and tear, and they choose a method convenient for themselves. This reflects the contradiction of government, on one hand, they plan to use public cultural buildings to activate people's life and enhance the cultural taste, on the other hand, they hope that the buildings can be kept intact and worry too many people pouring in without paying a fee. In some important events, for example, welcoming the visit of foreign presidents or leaders of central government, the public space, fountain in front square and grand lobby are operated in full swing. They eventually see cultural building a facelifting "view only" treasure, instead of an intimate utility/ place for the majority people.

\section{Conclusions: quest for city and people}

Since the 1980s, the process of China's reform, opening up, and urbanization have become the hallmarks of China's social development. Among the urban spectacles (Debord, 1995), cultural buildings have long been used as landmark or milestone for upgrading cities. As jewel on the crown, grand theaters in China were used as education and symbol of power in Mao's era, and for fame, capital and successful index in the open-door period (Ong, 2011). This paper briefly reviews the heat of constructing grand theaters using Shanghai as a case study. The surge of urbanization brings large number of people to the city, and new towns have to be built to accommodate new urban functions and residents. For old city like Shanghai, it has strong ambitions to restore its glorious past in economy and culture to lead the country. The newly built districts on remote areas need landmark cultural buildings to sparkle and make noise. To answer the question raised in the beginning of this article, so many grand theaters were built for Chinese cities' upgrading in economy and culture. The construction of grand theaters stimulates cultural production and consumption. Ideally, they provide new cultural space and enrich people's life.

After the major theaters, other cultural buildings and the subway network (705 km long) are completed, Shanghai plans to jump from an "international metropolis" by 2020 to a "global city" by 2040 that possesses a configuration of international resources, influence and high competitiveness (Shen et al., 2016; Owens, 2013). Such cultural venues are indispensable for a city with this global ambition. In the $13^{\text {th }}$ Five-year Plan of Shanghai's Economic and Social Development issued in 2016, "Enhancing Cultural Soft-power" stands as a chapter. Cultural soft-power is seen as an important means of enhancing a city's cohesion and "core" competitiveness. The important facilities, events and leading masters should be fully utilized to improve the deep integration of culture, economy and society. Aligned with London, New York, Tokyo and Paris, Shanghai launched and issued "cultural monitoring report" in 2011. More than 60 indicators are recorded the same time in these world cities. Number of performing art places and seats is one of them (Owens, 2013).

From the layer of cultural production, art works and creative activities ask for qualified space to display or perform. From the bottom layer of citizens, the increasing wealth and middle class look for more outlets to consume and experience. They are the results of government-led gentrification. The authors have investigated more than 10 Chinese cities, and observed averagely $80 \%$ theater occupancy. ${ }^{5}$ As the theaters are constructed for the city's branding and consumerists, they are stylish and symbolic in image. This phenomenon dialogues with the discussion on post modernism and consumerist society

\footnotetext{
5 See S. Zukin (1993). As we repeatedly mention, China’s gentrification is mainly driven by the administrative power and will. The authors' team has carried on investigation of Chinese theaters since 2013, and attended around 50 performances in various cities. The team also closely monitors the record of box office in different theaters.
} 
(Featherstone \& Lash, 1999; Kong et al., 2015). In terms of newly built theaters and total seats, Shanghai is among the advanced rank in the world. Shanghai Grand Theater alone hosted 367.000 people to see performances during fiscal year 2015-2016 (Shanghai Grand Theater, 2017). Similar number of people is seen in Oriental Arts Center and other venues. Each theater has attracted international artistic troupes to perform or hosted art festival. The hardware displays its value in catering the various activities. The forces from the above three aspects yield seemingly over-numbered cultural buildings.

To satisfy the ambitions of government and the eyes of increasingly picky audience and public, cultural buildings must be designed in a way to be compatible to the trend of the $21^{\text {st }}$ century. A theater should not only facilitate performance, but convey meaning in mass media/communication and earn fame and capital for the beneficiary (Klingmann, 2007). In China, the beneficiary is mainly government who makes the decision. This is a bit different with capitalist society. Chinese architecture with its old momentum could never fulfil such a grand task, and international architects are therefore called for bidding. The wide employment of international design firms is the result of architectural globalization. The convenience of communication and method of international firms serve China to realize its dream. The traditional shoebox form was wrapped with post-modern and post-industrial cloth, which is expected to express visibly new and futuristic kind of urbanity, and identified with the particular areas and city. The radical design can mostly convince the jury members and hence the decision makers. The prominent theaters were all designed by international architects and firms, which is more expensive than using local architects. ${ }^{6}$ This shows the city's determination to join the global cultural exchange and make a gesture of mind-opening. The designs of landmark buildings partly realized their intentions. In an assessment of the image of Shanghai's cultural space, Shanghai Grand Theater was rated No. 6 and the Oriental Arts Center No. 8. ${ }^{7}$

When the cultural buildings and grand theaters stand in new district or old areas, they can mostly provide adequate number of performances, particularly in advanced city like Shanghai. However, most of these theaters shut their doors during the day time. Although the design schemes considered public use and accessibility, most theaters' social function extends only an hour before the

\footnotetext{
6 It is estimated that the design fees of international architects are around four times higher than those of local architects. Organising an international design competition involves compensation fees for the shortlisted firms, logistics for meetings and a jury panel. See Xue (2010).

7 This is taken from an investigation made by Shanghai Investment Consultancy Ltd. in 2014. From Shen et al. (2016). No. 1 to 5 of impressive cultural spaces are Oriental Pearl (TV tower), The Bund, Yu Garden, Shanghai Museum, China Arts Palace (China Pavilion in the World Expo).
}

show, as the lobby opens at 6.30 PM for the audiences. The actual use of indoor common space severely abuses the original design thinking. Compared to the huge investment they require, the magnificent space and prominent status they present in the city, and the citizens' high expectations, Chinese theaters' social functions need to be better and more fully displayed.

Conclusively, the mushrooming of grand theaters in China is a result of rapid urbanization in the tide of globalization. It is a concerted effort of many stakeholders. The government develops and builds grand theater to realize its aspiration of being an unrivalled great city. The achievements of construction and economic growth can honour the municipal leaders and send them moving on in career ladder. The international designers get the opportunity to announce their statement of creative forms of design, they usually do not have such an opportunity in their home countries. The design and building quality of the grand theaters stand out from the trajectory of Chinese architecture, and can be comparable with those international role-models in competing cities. They smashed Chinese architects' "iron bowl" and set trends and examples in the design of cultural buildings. Chinese design firms learn from the starchitects through cooperation. Artist troupes have either home to rehearse or stage to perform. International artists and musicians obtain more markets in China. The middle class in the Chinese cities has more choices in cultural entertainment. However, as pointed out above, the well-conceived indoor public space has mostly not been fully used by members of public. No matter how excellent the hardware is, public buildings should serve the people fairly, particularly the grass roots.

In less than 20 years, Shanghai has restored the old concert hall and built nearly ten grand theaters, a dance theater, a play house, a concert hall and a circus city. Shanghai's path of building cultural spaces represents the development trajectory of Chinese cities in the $21^{\text {st }}$ century. However, Chinese cities and their people also deserve more enjoyment and sharing of cultural facilities and their affiliated public space. In the end, governments should be held accountable for the use of taxpayers' money, a public building should serve people and a city should make people's lives better.

\section{Acknowledgements}

This paper is part of a study supported by the Research Grant Council, Hong Kong government, Project No. CityU 11658816, and City University of Hong Kong, Project No. 7005135, 7005247. The authors heartily thank Mr. Huang Wenfu and Ms. Li Shuan for their great help in Shanghai theater study; and the kind sharing of Zhang Xiaoding, Pan Lan and Engineer Wu from Shanghai Grand Theater and Li Yan from Shanghai Oriental Art Center. The authors sincerely thank the constructive comments from anonymous reviewers and editor. 


\section{References}

Ando, T. (2015, July). The challenges of creating a cathedral to culture. $A+U$, Special Issue on Poly Grand Theater, 3, 24-27.

Andreu, P. (2015). Archi memories. CITIC Press.

Bourdieu, P. (1984). Distinction: a social critique of the judgment of taste. Harvard University Press.

Chang, T. (2000). Renaissance revisited: Singapore as a "global city for the arts". International Journal of Urban and Regional Research, 24(4), 818-831.

https://doi.org/10.1111/1468-2427.00280

Chen, J., Qi, X., \& Chen, J. (2015). Multi-collisions in the kaleidoscope - a review of Shanghai Jiading Poly grand theatre. Time + Architecture, 1, 120-125.

Cheng, Y. (2015). Contemporary performing arts architecture in the multidimensional perspective. China Architecture and Building Press.

Debord, G. (1995). The society of spectacle. Zone Books.

Enright, T. (2016). The making of grand Paris. MIT Press. https://doi.org/10.7551/mitpress/10476.001.0001

Featherstone, M., \& Lash, S. (Eds.). (1999). Spaces of culture: city, nation, world. Sage.

Gates, B. (2014). Have you hugged a concrete pillar today? GatesNotes: The Blog of Bill Gates. https://www.gatesnotes. com/Books/Making-the-Modern-World

Grenfell, M. (2004). Pierre Bourdieu: agent provocateur. Continuum.

Hong Kong Cultural Center. (2017). Annual Report of Hong Kong Cultural Center, 2014-2016.

Izenour, G. C. (1996). Theater design. Yale University Press.

Jencks, C. (2004). The architecture of the jumping universe: A polemic: how complexity science is changing architecture and culture. Academy Editions.

Klingmann, A. (2007). Brandscapes: architecture in the experience economy. MIT Press.

Kong, L., Ching, C., \& Chou, T. (2015). Arts, culture and the making of global cities - creating new urban landscape in Asia. Edward Elgar. https://doi.org/10.4337/9781784715847

Lee, L. (1999). Shanghai Modern: the flowering of new urban culture in China. Harvard University Press.

Ma, W. (2015, July). Interview with Sun Jiwei. $A+U$, Special Issue on Poly Grand Theater, 3, 42-47.

Mao, Z. (1991). Zai Yan'an wenyi zuotanhui shang de jianghua (Speech at the Yan'an forum on literature and art, 1943). In Mao Zedong xuanji di san juan (pp. 847-848). Beijing: People's Publishing House.

Ministry of Culture. (2007). Wenhua shiye fazhan jiuwu jihua he 2010 nian yuanjing mubiao gangyao [Development plan of cultural affairs and the vision of 2010]. Ministry of Culture.

Murray, P. (2004). The saga of the Sydney Opera House: the dramatic story of the design and construction of the icon of modern Australia. Spon Press. https://doi.org/10.4324/9780203358160
Nippon Shekki. (1995). Architectural design of Oriental Music Hall. Time + Architecture, (4), 8-10.

Ong, A. (2011). Hyperbuilding: spectacle, speculation, and the hyperspace of sovereignty. In A. Ong \& A. Roy (Eds.), Worlding cities: Asian experiments and the art of being global. WileyBlackwell. https://doi.org/10.1002/9781444346800.ch8

Owens, P. (2013). World cities cultural report. Tongji University Press.

Shanghai Statistic Bureau. (2018). Shanghai Statistic Annual Report. Shanghai, Statistic Bureau.

Shen, L., Lu, W., \& Wang, B. (2016). Strategic thinking on the cultural spatial planning of Shanghai towards a global city. Urban Planning Forum, 3, 63-70.

Shanghai Grand Theater. (2017). 2015-2016 Annual Report. Shanghai, Shanghai Grand Theater.

Short, J. R. (2004). Global metropolitan: globalizing cities in a capitalist world. Routledge.

Smil, V. (2014). Making the modern world: materials and dematerialization. John Wiley \& Sons, Ltd.

Sun, C. (2019). Appendix I, Database of grand theaters in China: 1998-2018. In C. Xue (Ed.), Grand Theater Urbanism - Chinese cities in the $21^{\text {st }}$ century. Springer.

Wu, C. (2012). Shanghai Oriental Arts Center - Interviewing Cui Zhongfang, chief architect. Jianzhu Jiyi (Architectural Technology), (4), 54-57.

Xue, C. Q. L. (2006). Building a revolution: Chinese architecture since 1980. Hong Kong University Press.

Xue, C. Q. L. (2010). World Architecture in China. Joint Publishing Ltd. Co.

Xue, C. Q. L., \& Ding, G. (2018). A history of design institutes in China: from Mao to market. Routledge. https://doi.org/10.4324/9780203709917

Xue, C. Q. L., \& Zhou, M. (2007). Importation and adaptation: building "One City and Nine Towns" in Shanghai, a case study of Vittorio Gregotti's plan of Pujiang Town. Urban Design International, 12(1), 21-40. https://doi.org/10.1057/palgrave.udi.9000180

Xiao, L. (2015). The record of global city forum on the first UN world cities day. Shanghai People's Publishing House.

Yang, Z. (2016). Dajuyuan de 'zhengzhi xushi' ji dui chengshi wenhua de suxing [The "political narration" of the grand theater and its shaping of the urban culture]. Henan shehui kexue [Social Science of Henan], 24(3), 115-122.

Yu, J. (2014). Pobing zhilv - shanghai dajuyuan xunli [Breaking the ice - road of Shanghai Grand Theater]. Shanghai Jiaotong University Press.

Zukin, S. (1993). Landscape of power: from Detroit to Disney World. University of California Press.

Zhang, Z. M. (2005). Urban development and urban comprehensive competitiveness in Modern Shanghai. Shanghai Academy of Social Sciences. 